\title{
The TUC and the Failure of Labour's Postwar Social Agenda
}

\author{
Dennie Oude Nijhuis
}

Leiden University

\begin{abstract}
This article illustrates the crucial role played by the Trades Union Congress and its occupationally organized union affiliates in the failure of Labour's postwar social agenda. It has been widely recognized that Labour's inability to improve the social insurance system and construct an effective floor under wages during the first decades of the postwar period was of crucial importance to the continual underdevelopment of the British welfare state and the emergence of a dual welfare system in the United Kingdom. Yet that Labour's inability to do so was to a large extent the result of union opposition has largely been neglected. This article shows that Labour's postwar social agenda had strong consequences for the distribution of earnings among different groups of workers and that these consequences were fiercely resisted by unions representing privileged workers. In doing so, this article illustrates the limited political feasibility of government measures to provide adequate earnings and security against labor market risks for all workers in countries where privileged workers largely organize along occupational lines.
\end{abstract}

During the 1950s and 1960s, the Labour Party and Britain's largest labor union federation, the Trades Union Congress (TUC), were strongly at odds over several of Labour's proposals to improve the security and earnings of workers in the United Kingdom. These included the introduction of statutory severance pay for all workers, a public pension reform known as superannuation, the introduction of a statutory national minimum wage, and a promise to achieve nothing less than a "new deal" for the disabled. None of these proposals could count on unqualified TUC support. Some, like the superannuation proposal and new deal for the disabled, only received full TUC support after lengthy negotiations in which Labour agreed to make substantial changes to these proposals. Others, like the statutory national minimum wage and severance pay proposals, the federation rejected outright. This critical reception was not without its consequences. Had most of Labour's proposals been enacted, the United Kingdom would have come to resemble its continental European neighbors much more closely in terms of the generosity of its welfare state and ability to construct an effective floor under wages. As it were, and despite the fact that Labour was in power during much of this period, few of these proposals were enacted in their original form - if at all. Labour's inability to do so proved to be a crucial moment in British history, as it effectively marked the end of its postwar social agenda. ${ }^{1}$ 
This article illustrates the crucial role played by the TUC and its affiliates in the failure of Labour's postwar social agenda. That this failure cemented the emergence of a "dual" welfare system in the United Kingdom, which granted increasingly generous security to highly paid, low-risk workers while many other workers continued to lack adequate insurance as well as wages, has long been acknowledged. ${ }^{2}$ Yet the crucial role played by the labor union movement in this development has been largely neglected. In fact, both the new literature on the emergence of dual welfare systems as well as conventional writings on postwar welfare state development generally treat labor unions as key supporters of efforts to improve the security and earnings of workers, including their redistributive consequences. ${ }^{3}$ This article argues against this treatment. It does so by illustrating that Labour's proposals had strong consequences for the distribution of income and risk among different categories of workers, and that these consequences were vehemently opposed by unions representing more highly paid, less risk-prone workers. In doing so, it emphasizes the importance in the United Kingdom of occupationally organized unions that seek to limit their membership to skilled, and thus privileged, workers. Contrary to more inclusive types of labor unions, such unions cannot be expected to support measures that result in a redistributive effort between different categories of workers. The distinction between these types of unionism is well known in the literature. ${ }^{4}$ Yet the consequences of this for labor market and welfare state development have been far from broadly acknowledged. On the contrary, most of the literature continues to proceed from an implicit assumption that the behavior and interests of labor unions are roughly equivalent across and within countries. ${ }^{5}$

The following analysis illustrates the importance of these organizational features. It does so by demonstrating that Labour's proposals were in clear conflict with the main organizational purpose of the TUC's occupationally organized affiliates-to preserve existing wage differentials between their members and less-skilled workers. It further demonstrates that the TUC's critical stance of these proposals was a direct result of this. In doing so, it also critically examines other possible explanations for the TUC's lack of support for Labour's proposals. One such explanation may be that its affiliates were simply reluctant to hand over key union functions to a potentially hostile government. This explanation, which emphasizes the importance of distributive class conflict, is often used to justify the TUC's longstanding opposition to the introduction of a statutory national minimum wage in the United Kingdom. Most studies on this have emphasized union fears that such a move might undermine their "purpose" and, with that, their ability to attract workers. ${ }^{6}$ Some of them have further argued that these fears were compounded by government publications such as In Place of Strife, which proposed union reform and threatened to weaken the ability of unions to engage in industrial action. Under these circumstances, it is often argued, it was simply unthinkable that any increase in government involvement in the wage determination process would be accepted. ${ }^{7}$ 
This article shows that these considerations were of much less importance to the TUC's stance and that of its occupationally organized union affiliates than concerns over the redistributive consequences of statutory intervention. It does so by illustrating that both the TUC's main governing body, the General Council, and the fiercest opponents of statutory intervention within the federation, its craft union affiliates, worried mainly about the consequences of such intervention for existing wage differentials. The analysis first demonstrates that the TUC's occupationally organized union affiliates consistently opposed any measure that resulted in a redistributive exercise between their members and lower-paid, more risk-prone workers. It then illustrates the consequences of this for the proposals put forward by Labour during the 1950s and 1960s. The analysis concludes with a broader exploration of the political feasibility of government measures to provide adequate earnings and security against labor market risks for all workers in countries, like the United Kingdom, where privileged workers largely organize along occupational lines-and thus separate from other workers. In doing so, it emphasizes that such measures cannot be successful without a redistributive effort among different categories of workers.

\section{Labor Unions and the Redistributive Consequences of the Postwar Welfare State}

Labour's postwar attempts to make sure that all British workers were able to obtain adequate earnings and security against labor market risks had strong consequences for the distribution of income among different groups of workers in the United Kingdom. These efforts were vehemently opposed by unions representing privileged workers who consequently stood to lose from these redistributive consequences. The economic strength of these largely occupationally organized unions made sure that their resistance was quite successful. The presence of a powerful occupationally organized union movement, which consistently opposed any measure that resulted in a redistributive effort between its members and lower-paid and more risk-prone workers, was thus of central importance to the failure of Labour's postwar redistributive agenda. As a result, it was also of crucial importance to the continual "underdevelopment" of the British welfare state and emergence of a dual welfare system in the United Kingdom. ${ }^{8}$ Despite its importance, the existing literature on welfare state development has largely failed to recognize this.

To a large extent, this neglect may be attributed to the strong preoccupation with class divisions and the resulting tendency to emphasize labor unity against capital, in much of this literature. To be sure, this preoccupation has by no means been limited to writings on postwar British welfare state development. For several decades now, most understandings of the modern welfare state have proceeded from the premise that the postwar creation and expansion of social programs, like most other forms of government intervention in the labor market, mainly involved distributive class conflict. ${ }^{9}$ The outcome of this conflict is subsequently viewed as primarily resulting from the distribution of "power resources" between contending classes. For practical purposes, these 
classes are often defined in the broadest possible way, whereby major socioeconomic groups such as workers and employers are viewed as more or less homogenous groups with similar risks and resources, and thus with similar interests. ${ }^{10}$ Based on an implicit acceptance of these premises, much of the literature continues to view the postwar expansion of the welfare state as the outcome of a consensual strategy of national labor union movements empowered by wartime and postwar political processes. ${ }^{11}$

In recent years, this conventional "labor-oriented" view of modern welfare state development has been subjected to much criticism from what can be broadly described as an employer-oriented scholarship. The main purpose of this scholarship has been to demonstrate that employers have played a more important, and often also a more constructive, role in the development of the postwar welfare state than generally realized. According to what arguably constitutes its most successful variant, some-but, crucially, never all-employers supported the postwar expansion of particular social programs in order to level the playing field or to off-load costs onto competitors or society as a whole. ${ }^{12}$ Although its claims remain controversial, this scholarship oriented in "cross-class alliance" has certainly been successful in demonstrating that employers do not constitute a homogenous group with similar risks and resources and consequently do not necessarily have the same interests. As recently demonstrated by a series of writings that pointed to various instances of intralabor conflict over welfare state retrenchment, the same obviously goes for workers. ${ }^{13}$

To date, this has not led to a major reappraisal of organized labor's role in welfare state development, though. On the contrary, nearly all recent writings have continued to proceed from the assumption of labor union support for the process of postwar welfare state expansion. This includes those writings that have focused on countries, like the United Kingdom, that are characterized by strong, occupationally organized union movements. ${ }^{14}$ That the emergence of "dual" welfare systems in these countries is inextricably linked to the strength of occupationally organized unionism there has not been broadly recognized. Instead, the great reliance on private benefits in these countries is almost unanimously attributed to employer pressure. ${ }^{15}$ This is surprising, because several recent writings have noted instances of strong (and often occupationally based) union opposition to public welfare development. These instances, however, are mostly explained through union fears over allowing a potentially hostile government to undermine key union functions. ${ }^{16}$ At best, they are explained by arguing that the emergence of generous private programs eventually worked to "reorient labor's interests ... leading many unions to prefer privatesector solutions over public-sector ones." ${ }^{17}$ Both explanations, as we will see, crucially neglect the distributive considerations behind these instances of union opposition.

Most of the recent scholarship on employers treats labor unions in a similar way. This includes those writings that have criticized conventional accounts for assuming that there is an "equivalence of interests among like classes in different countries," and subsequently themselves apply a similar equivalence to 
organized labor's preferences and political behavior. ${ }^{18}$ It also includes those writings that have focused on the United Kingdom and argued that "the social policy preferences of the British labor union movement in the first decades after the Second World War were in no way different from the preferences of [the mostly industrially organized] unions in Germany and Sweden." To be sure, and following conventional labor-oriented accounts of the welfare state, the idea here is that the labor union movements in all these countries provided undivided support for wage compression policies and the expansion of the welfare state. ${ }^{19}$ Finally, it includes those writings that have pointed to instances of fierce intralabor conflict over recent welfare state reforms, but at the same time presume that the postwar expansion of the welfare state could count on the support of a "unified left...because the overall direction was expansive." 20

Such views crucially neglect that this expansion was not necessarily in the interests of all workers. The postwar creation and expansion of social programs, for instance, did much more than merely provide workers with security against labor market risks. Through risk reapportioning and the introduction of systems of contributions and benefits that increasingly worked to the advantage of the lowest paid, it also massively redistributed risk and income among different groups of workers. These redistributive consequences increased as the postwar period progressed, and left governments became more concerned with improving matters specifically for workers who as a result of a high risk profile and low wages - two features that often go together because they in turn depend greatly on a worker's skill profile - were often unable to obtain adequate security against labor market risks without a redistributive effort from more privileged workers. To be sure, other types of government intervention, such as the introduction of a statutory national minimum wage, likewise had strong consequences for the distribution of income among particular groups of workers.

These redistributive consequences were by no means automatically accepted by all workers. Nor, as a result, could they automatically count on broad organized support from workers. Such broad support was in fact unlikely in countries characterized by strong occupationally organized unions. After all, in such countries, those workers who stood to lose from these redistributive consequences largely organized separately from those who stood to gain from it. As a result, they could not be forced to accept these consequences by a majority of lower paid, more risk-prone workers. ${ }^{21}$ To a large extent, this is why they organized separately in the first place. Whether in the form of craft unions representing skilled manual workers or in the form of associations for specific groups of white-collar workers, it is crucial to note that the organizational logic of such unions were grounded in the occupational defense of wage differentials against lower skilled workers. ${ }^{22}$ As a result, they were unlikely to support the redistributive consequences of the introduction and expansion of social programs and other forms of government intervention in the labor market. Moreover, and as we will see, as unions representing workers with a strong 
position on the labor market, they had substantial economic leverage to prevent such intervention from coming about.

\section{The Importance of Occupationally Organized Unionism in the United Kingdom}

This leverage can be expected to have been largest in countries, like the United Kingdom, where nearly all skilled manual workers and the vast majority of white-collar workers with a clear skill profile organized in separate occupationally organized unions. During the first decades of the postwar period, when the welfare state expanded most rapidly in the United Kingdom, occupationally organized unions accounted for roughly thirty percent of all organized workers there. ${ }^{23}$ Although never representing a majority of organized workers, these unions did represent Britain's most skilled occupations. As a result, their economic and political leverage was in no way proportionate to the amount of workers they organized. The continual ability of Britain's powerful craft unions to defend the skill differential of their members' wages over those of semiskilled and unskilled manual workers during most of the twentieth century, despite representing a steadily dwindling share of the total union membership, testifies of this. ${ }^{24}$ Their ability to defend these differentials simply did not rest on numbers; instead it rested on the exclusive nature of their members' skills.

The presence of a powerful, occupationally organized union movement that was strongly committed to defending existing wage differentials clearly had strong consequences for the postwar trajectory of the British welfare state. It simply made it very difficult to pass measures that specifically aimed to improve the earnings and security against labor market risks of lower paid and more risk-prone workers. After all, such measures were quite likely to result in a reduction in the occupational wage differential. Given the common tendency to apply an equivalency premise to organized labor's interests across time and among different countries, it is important to note that the United Kingdom differed crucially in this respect from most continental European countries where a more inclusive type of unionism dominated. As demonstrated by a host of writings over the years, the industrially organized union movements in these countries were generally quite willing (and surprisingly able) to support measures that resulted in a redistribution of risk and income among different categories of workers during the first decades of the postwar period. To be sure, the "winners" and "losers" of these measures often belonged to the same union. ${ }^{25}$

In the broader literature on labor market development, it has long been recognized that the British union movement has through most of the twentieth century been far more reluctant to accept redistributive government intervention in the labor market than most of its continental European counterparts. That this reluctance often focused specifically on these redistributive consequences is not broadly recognized, though. Instead, it is generally attributed to an ideological commitment to "voluntarism," which in turn supposedly 
rested on a historic distrust of state solutions and union fears that increased state intervention might affect their future ability to attract workers to union membership. ${ }^{26}$ That this distrust was apparently much greater among those unions that mainly organized privileged workers is largely neglected. ${ }^{27}$ Nor have existing writings given much attention to the often-noted fact that the British union movement's commitment to voluntarism was by no means consistent. ${ }^{28}$ Indeed, and as we will see, it was generally most severe when occupationally organized unions were confronted with measures that affected existing wage differentials.

To be sure, the British union movement has at times displayed the greatest readiness to accept state intervention. For instance, in 1946 it gave its full support to a measure that arguably involved the greatest increase in such intervention thus far: the National Insurance Act, which granted universal protection against a wide range of labor market risks. One year later, and somewhat more hesitantly, the TUC also supported the Wages Councils Act, which established minimum wages and other conditions for employees in certain industries. ${ }^{29}$ In future years, the TUC would continue to support far-reaching forms of legal enactment. Many of these related to conditions of employment, and thus involved those key union functions that attracted workers to union membership. Yet none of them had clear consequences for existing wage differentials. This was not just the case for the Wages Council Act, which was merely devised to prevent sweating in those industries in which union organization was largely absent-or in other words, where the problem of low pay was not related to the question of wage differentials. ${ }^{30}$ It was also the case for the newly established "egalitarian" national insurance system.

That broad union support for the National Insurance Act had only been possible because its egalitarian system was inherently conservative is far from broadly recognized in the literature. On the contrary, according to Derek Fraser, for instance, the "flowering of egalitarianism" resulted from a "progressive consensus," which in turn resulted from the "spirit of the 1940s engendered by the war [that] dictated the necessity of the natural justice of universalism where everyone was treated in the same way." 31 In line with this view, Hugh Pemberton explained the creation of the system by arguing that "the war contributed to a solidaristic environment." 32 In reality, the choice for an egalitarian system had nothing to do with its universal nature, though. Nor did it result from "solidaristic" considerations. Had this been the case, then its founding fathers may have followed the suggestion of organizations like Political and Economic Planning (PEP) and the Association of Approved Societies (AAS), which proposed combining flat-rate benefits with contributions graduated by income. ${ }^{33}$ Instead, all involved parties opted for a completely flat-rate contributory system. This included the TUC, whose General Council argued that if the scheme was to be contributory, it would have to operate along egalitarian lines. ${ }^{34}$ And when Labour politicians several years later considered adopting a more redistributive system that was similar to the one suggested by the PEP and AAS earlier, the General Council immediately rejected this. ${ }^{35}$ 
In this, the TUC crucially differed from, for instance, its industrially organized counterparts in the Netherlands. When confronted with an egalitarian old-age pension scheme that was devised by a friendly left-oriented government in the early 1950s, the largest union federation in the Netherlands, the Dutch Association of Trade Unions (Nederlands Verbond van Vakverenigingen), responded with a counterproposal that was quite similar to the one the TUC was just about to reject in the United Kingdom. The other main union federations in the Netherlands immediately gave their full support to this proposal, which was enacted several years later. ${ }^{36}$ In most other continental European countries, the industrially organized union federations over time also pushed for, or at least supported the coming about of, a contributory system that was in one way or another redistributive. In Germany, for example, the major unions supported the introduction of a flat-rate minimum into the existing earnings-related pension system during the late 1950s. ${ }^{37}$ The Swedish Trades Union Confederation (Landsorganisationen $i$ Sverige) also frequently pushed for redistributive proposals. ${ }^{38}$ In the United Kingdom, by contrast, the TUC never wholeheartedly supported redistributive contributory social security initiatives. On the contrary, and as we will see, the federation even opposed initiatives that merely aimed to broaden the scope for risk redistribution among different categories of workers.

The crucial difference between the mostly industrially organized union federations of continental Europe and the TUC was that many of the latter's affiliates consisted of occupationally organized unions that resisted any attempt to reduce the occupational wage differential. During the late 1940s, and in a series of moves that strongly contributed to the collapse of the voluntary incomes policy, these unions had already made it clear that they were unwilling to accept wage bargaining outcomes that resulted in a reduction in the occupational wage differential. ${ }^{39}$ In future years, they would make it clear that they also resisted any government measure that adversely affected the occupational differential. This stance presented the Labour Party with a rather troubling dilemma that most of its left counterparts on the European continent never had to face. After all, without a significant reduction in the occupational differential, Britain's most disadvantaged workers could neither hope to achieve neither above-subsistence-level earnings nor adequate security against labor market risks.

\section{Occupationally Organized Unionism and the Limits of Social Security Reform}

As Labour's postwar agenda included making sure that all of Britain's workers could obtain adequate wages and security against labor market risk, this inevitably set it on a collision course with Britain's occupationally organized unions. When Labour's proposal to combine flat-rate benefits with earnings-related contributions was rejected by the TUC in the early 1950s, it received a first taste of what was to come. Since Labour had not been fully committed to this proposal, this rejection probably had little effect on its relationship with the TUC. ${ }^{40}$ The same could not be said for an alternative proposal that was 
promoted by Labour several years later. This so-called national superannuation proposal, which was put forward by Labour in October of 1957, aimed to grant an earnings-related supplement to the flat-rate old-age pension benefit that was paid for by earnings-related contributions. The scheme was somewhat redistributive, as part of these contributions was to be used to finance an increase in the existing flat-rate benefit. This meant that more highly paid workers were to lose out in both absolute terms as they would receive less than they put into the scheme and relative terms as it was the lowest paid that would benefit from this. As the former often had access to (increasingly generous) private pension schemes, this effectively meant that they now faced the introduction of a public scheme that diverted a substantial part of their private pension contributions to pay for increases in benefit generosity for low-paid workers.

This provoked fierce protests from unions representing these workers, which in turn forced the TUC to take a rather skeptical stance regarding superannuation. In a meeting on the matter with Labour representatives, TUC officials merely descripted the scheme "as sufficiently attractive in principle to warrant further examination." 41 In addition, they demanded that who already had access to private supplements were to be given the possibility to opt-out. This demand obviously presented Labour strategist with a dilemma as they realized that when large groups of workers opted-out from the public scheme into private schemes, it would become impossible to finance benefit increases for lower paid workers. As a result, they agreed to grant an opt-out possibility, but initially did so only for existing members of private scheme. TUC officials immediately rejected this as wholly insufficient, however, as it effectively meant that existing schemes would "wither away" as they "depended on new entrants for their continued solvency." 42 Following discussions that took over a year, the Labour Party consequently gave in an informed TUC officials that the opt-out was to be extended to new entrants as well in May of 1958. This proved enough to give Labour's superannuation scheme a cautious welcome at the annual TUC conference later that yer. ${ }^{43}$ When Labour lost the general elections the following year, the plan was immediately shelved.

Some scholars have argued that if the Labour Party had been able to introduce superannuation, the United Kingdom would have become one of the most generous welfare states of its day. ${ }^{44}$ Yet the important point is that it had not been able to do so. Even if Labour had won the elections, then the concessions it had been forced to make would still have prevented the scheme from being implemented in its original redistributive form. After all, it allowed all workers who stood to lose from the scheme's redistributive consequences to opt-out. Some 10 years later, when Labour undertook a new attempt to introduce superannuation, events nearly repeated themselves. This time, Labour was in power when it proposed a complete replacement of the existing flat-rate scheme by a system that granted earnings-related benefits in exchange for earnings-related contributions. This so-called "Crossman-scheme" also contained a relatively high minimum benefit level, making it quite redistributive. In response, unions representing workers who stood to lose from this once 
more demanded a full opt-out. This time, the TUC only partially supported their demands, but it also successfully pressed the Labour government to accept a less redistributive formula. ${ }^{45}$ Labour finally managed to introduce a severely watered-down version of its original proposal into Parliament in the beginning of 1970, but then lost the general elections of June that year before it could implement the scheme. ${ }^{46}$

The failure of Labour's first two attempts to introduce superannuation was of momentous importance for the postwar trajectory of the British welfare state and has consequently received much attention in the literature. That the opposition of some unions played a role in this failure has also been acknowledged. Yet rather than viewing this opposition as the inevitable result of the occupational defense of the wage differential, most scholars have explained it as an outcome of the growth of the private pension sector, which over time supposedly worked to reorient organized labor's interests away from public welfare solutions. ${ }^{47}$ The problem with this explanation is that here is no evidence that such a reorientation ever took place. On the contrary, the TUC's support for an egalitarian system in the 1940s, its immediate rejection of Labour's proposal for a "Dutch-style" redistributive contributory solution in the early 1950s, and the opposition of unions representing affluent workers to national superannuation all seem remarkably consistent. Moreover, the claim that the growth of the private welfare sector worked to reorient organized labor's interests away from public welfare solutions assumes a dichotomy that may not even have existed in the minds of these unions. What mattered to them was simply how to achieve the best level of security for their members against the lowest costs. And here superannuation certainly fell short.

To those unions that catered for privileged workers, the main problem with superannuation was not that it threatened to transform private savings into public savings. Instead, it was that it did so on terms that were unfavorable to them. Unions like the Transport Salaried Staffs' Association made this quite clear at the 1969 meeting of Congress when they argued against the Crossman-scheme by warning that they could not accept attempts "to improve the position of the worse-off section of the community at the expense of those whose earnings were in the middle salary range." 48 They also made this clear during internal discussions in the General Council when they pointed out that the lower paid gained "advantage" under the new scheme, and subsequently pressed the Council "to see that all interests are looked after without prejudice." 49 That they were not willing to accept any advantage on behalf of the lower paid became clear when the General Council presented the outcome of its negotiations with Labour representatives, which included a sharply reduced but still somewhat redistributive formula. This compromise did little to appease opponents and was described by unions such as the National Federation of Professional Workers as "complete nonsense."50 These unions continued to fight superannuation tooth and nail until Labour, in a third attempt to get the scheme enacted during the mid-1970s, removed it of all its redistributive features. ${ }^{51}$ 
Those unions that resisted superannuation so fiercely naturally also resisted other social security initiatives that gave "advantage" to less privileged workers. During the late 1950s, they for instance rejected a Labour proposal to grant all workers one half of normal earnings for the first month of either redundancy or sickness. They motivated their resistance to this in the TUC Social Insurance and Industrial Welfare Committee by pointing out that Labour's plan "might hurt the position of unions during negotiations over collective agreements." 52 Of course, it was only those unions that catered for skilled workers, and who consequently had already been able to obtain severance and sick pay through voluntary bargaining, that worried about this. At the time, this was only the case for respectively a third and half of all British workers. ${ }^{53}$ The other two-thirds and one half of the workforce did not have access to respectively occupational severance pay and sick pay, and would have benefited from Labour's proposal. For many, this was the case because they worked in industries or occupations in which redundancy was so common that only public schemes, and the risk redistribution that they offered, could make adequate provision possible for them.

And this was obviously unacceptable to those unions that exclusively catered for skilled, and thus less risk-prone, workers. Representatives of these unions made this quite clear during internal discussions in the TUC subcommittee on sickness and unemployment benefits when they pointed out that under Labour's above-mentioned proposal, as a result of substantial risk reapportioning, the amount of foregone wages that were needed to finance adequate sickness and unemployment benefits would be much higher under occupational schemes. This, they argued, would be unacceptable to their members. ${ }^{54}$ When confronted with a Labour plan to grant statutory earningsrelated supplements to the state unemployment and sickness benefits for a period of up to 6 months in the mid-1960s, unions like the Clerical and Administrative Workers Union (CAWU) similarly pointed out that "sickness and unemployment benefit differed from retirement pension in that the contingencies against which they were intended to give protection, affected the more highly paid less than the lower paid." This made it "undesirable to put too heavy a burden directly on those with the smallest risk," especially since "many higher paid workers would resent a higher level of contributions for benefits which might mean little to those in tolerably secure position." 55 In addition, they warned that their members could not accept any attempt to introduce redistributive elements into the national insurance scheme. ${ }^{56}$

For the TUC, the objections of its more privileged affiliates were important enough to dismiss Labour's 1950s' statutory severance and sick pay proposal out of hand. It, by contrast, gave a cautious welcome to Labour's proposal to grant earnings-related supplements to the state unemployment and sickness benefit during the mid-1960s. Part of this difference may be attributed to strategic considerations. In 1964, Labour had returned to power and was therefore once more a force to be reckoned with. Important also was that the new government worked hard to appease the occupationally organized section of the union 
movement by making sure that the latter proposal was hardly redistributive: No part of earnings-related contributions were used to finance an increase in the existing flat-rate benefit, and strict contributory requirements severely limited the scope for risk redistribution. ${ }^{57}$ The supplementary proposal was enacted in 1966. One year later, and despite strong protests from both the TUC and the major employer confederations, Labour also introduced a Redundancy Payments Act that provided a minimum entitlement to a redundancy payment for employees who had a set period of service. ${ }^{58}$

That Labour was eventually able to enact its statutory severance pay proposal illustrates that the existence of strong labor union opposition did not make progressive welfare reform completely impossible in the United Kingdom. Yet there can be no doubt that it made such reform much more difficult to achieve. To be sure, the resistance of unions representing privileged workers to measures that affected the distribution of income among different categories of workers was quite consistent. It not only complicated Labour's attempts to provide all British workers with adequate security against labor market risks, but it also made it virtually impossible to make sure that all workers were able to obtain adequate (above-subsistence) wages. This became painfully clear in the mid-1960s when the TUC flat-out rejected a Labour government proposal to address the problem of low pay through the introduction of a statutory national minimum wage for all workers. Despite strong pressure from the Labour Party, the TUC would continue to oppose the introduction of a national minimum wage through legislative means for another two decades. In doing so, it helped to make sure that the United Kingdom remained one of the few European nations that failed to construct a common floor for wage levels in the twentieth century. ${ }^{59}$

\section{The Failure of Labour's First Attempt to Introduce a Statutory National Minimum Wage}

The TUC's longstanding opposition to the introduction of a statutory national minimum wage has been the subject of much scholarly research over the years. Earlier I mentioned that much of this research has emphasized traditional class-based considerations such as union distrust of state motives or their fears that statutory intervention would undermine their "function" and with that their ability to attract new workers. I also mentioned that some scholars have argued that these fears were compounded by a Labour proposal for union reform in the late 1960s. Emphasizing Labour's consistent pursuit of income policies based on wage moderation during the 1960s and 1970s, other scholars have cited union fears that the introduction of a statutory national minimum wage would put a ceiling on wage rises. Again, others have argued that the union movement was simply reluctant to accept more statutory interference without receiving a guarantee that the "government would either introduce, or establish, a minimum at a level acceptable to the unions." 60 That the government's inability to do so primarily resulted from the occupational defense of the wage differential is far from widely recognized, though. ${ }^{61}$ 
Empirical evidence suggests that this defense was in fact of prime importance to this. When the Labour Party in the early 1960s turned its attention to the possible introduction of a statutory national minimum wage, it immediately noted that the persistence of poverty in employment could not only be attributed to the sweating practices of employers alone, as roughly half of all low-paid jobs could be found in highly unionized sectors in which average pay levels were relatively high. ${ }^{62}$ This meant that a solution to the problem of low pay required a much broader approach than the existing machinery of wage councils. ${ }^{63}$ Yet it also meant that the success of any solution to this problem depended on whether wage differentials could be compressed. After all, and as argued by a Labour working party, "profit margins of employers can only be squeezed so far" before they had to "pass costs on to consumers." 64 Unless wages could be compressed in the long term, the only result of the introduction of a statutory minimum wage would consequently be to "cause inflation by starting a wage round that would raise the whole earnings structure." 65 For obvious reasons, Labour representatives were quite skeptical as to whether such compression was possible in the United Kingdom. When Labour returned to power in 1964, it therefore did not immediately resort to statutory intervention to improve matters for the low paid. Instead, it attempted to obtain TUC support for income policies based on wage restraint in which substantial wage increases were limited to the lowest paid. ${ }^{66}$

It was only when this approach failed miserably and it became clear that the relative position of the unskilled in fact continued to worsen during the mid-1960s that the Labour government changed its course. In early 1967, it created an interdepartmental working party that was to prepare the ground for a possible introduction of a statutory national minimum wage. At the same time, the government made it clear that it did not want a firm commitment on the issue because of possible "adverse" effects. How large these effects would be, Labour officials emphasized, depended foremost on the response of the union movement. ${ }^{67}$ Little over a year after the creation of the working party, Labour representatives therefore formally consulted the TUC General Council on the government's intention to introduce a statutory national minimum wage. Here, the proposal was almost immediately rejected.

Of much importance to this swift dismissal was the negative response of many of the TUC's affiliates to Labour's minimum wage proposal. These affiliates did not just belong to the craft and occupationally organized white-collar union movement, as several general and industrial unions also expressed doubts about the merits of statutory intervention. Yet crucially, the latter did so for strikingly different reasons. Britain's largest labor union at the time, the Transport and General Workers' Union (TGWU), for instance, expressed its concern that statutory intervention might undermine its ability to attract workers in the future. ${ }^{68}$ Others, like the national Union of Railwaymen (NUR), the National Union of Mineworkers (NUM), and the national Union of Agricultural and Allied Workers (NUAAW) mainly doubted whether the introduction of a statutory national minimum wage would prove effective in 
improving matters for the lowest paid. Each of these unions would change their stance on the merits of statutory intervention in future years, though - with the TGWU being the last to do so. ${ }^{69}$

The reason for this is that their reservations were much less serious than those of Britain's occupationally organized unions, which much more firmly argued that "wage negotiations was a field in which statutory interference could not be tolerated." ${ }^{70}$ That their insistence on this was mainly motivated by redistributive considerations was made abundantly clear by craft unions like the powerful Iron and Steel Confederation (ISTC), which pointed out that the introduction of statutory national minimum wage would "retard the progress ... of those workers whose earnings were above the statutory minimum." ${ }^{, 71}$ This, the ISTC warned, would not be accepted by its members. To support its claim, the ISTC mentioned that when steel employers had some years ago suggested to concentrate wage increases on the low paid, their members had strongly opposed this. White-collar unions like the Civil and Public Services Association (CPSA) even went so far as to state that their membership was "unwilling to sacrifice ... any contraction of incremental scales in order to help those at the lower levels, essentially because many of those at the top felt low paid themselves."72

These unions also made it clear that they would seek to reverse any resulting reductions in wage relativities that their members might experience as a result of the introduction of a statutory national minimum wage. ${ }^{73}$ These warnings may go a long way in explaining why unions like the NUR, NUM and NUAAW doubted whether statutory intervention would prove effective in improving matters for the lowest paid. That these warnings were certainly taken seriously can be seen from an internal note that summarized the TUC's main concerns as follows:

The problem is that simply raising basic rates [for the low paid] may raise the wages of all workers by a proportionate amount; this general effect will limit the amount that can be allocated to the lower paid in the sense that there is an overall limit on what firms can afford to pay without raising prices. If they do raise prices, this will have a disproportionately adverse effect on the real incomes of the lowest paid workers in the economy in general. ${ }^{74}$

Under these circumstances, the introduction of a statutory national minimum wage would not only be "costly," it would also have little effect as "differentials would be rigidly maintained and ... prices increased to an extent that would wipe out the effects of the initial increase in low payment incomes."75

In sum, TUC concerns that the union movement would buy a "pig in the poke" by granting the state a larger role in the wage fixing process without having a firm commitment that this would indeed improve matters for the lowest paid were inextricably linked to the occupational defense of the wage differential. ${ }^{76}$ TUC officials were by contrast much less convinced that statutory intervention would have adverse effects on trade union organization. In an 
internal report on the matter, the members of the TUC's low-pay committee first noted that several decades of voluntary bargaining had done little to improve matters for the lowest paid. Like the Labour government had done several years before, they among others noted that low organization levels alone could hardly explain the persistence of low pay, especially since roughly half of the lowest paid occupations could be found in highly unionized sectors. In addition, the committee members pointed out that they were by no means convinced that the introduction of a statutory national minimum wage would make it more difficult to recruit low-paid workers in the first place. On the contrary, if its introduction could take place in steps, the committee argued, then its introduction would most likely be regarded as an outcome of union efforts. ${ }^{77}$

That the TUC nevertheless remained committed to the "normal process of collective bargaining to improve the position of the lower paid" consequently had more to do with wage differentials than with concerns over the organizational consequences of statutory intervention. In a formal response to the Labour government, the federation merely agreed to set unilateral declarations on what it regarded as adequate minimum wage levels in various industries. ${ }^{78}$ It did so even though it was quite aware of the limitations of a voluntary approach. A report written by the low pay committee neatly described these limitations by arguing that even if a unilateral declaration would result in "some employers paying more, it would hardly result in any trade unions asking for less."79 Despite its voluntary nature, several craft affiliates nevertheless warned that its introduction might "alienate higher paid workers whose differentials appeared to be narrowing adversely, and stimulate horizontal trade union organization based on earnings levels. ${ }^{80}$ Once the TUC made it clear that it rejected statutory intervention, the Labour government decided to back down - at least until after the general election of June 1970.

When Labour subsequently lost this election to the Conservatives, the proposal was shelved indefinitely. Although the introduction of a statutory minimum wage remained an official party goal, Labour did not push for it in the six years following its return to government in $1974 .{ }^{81}$ Nor did it embark on yet another round of ambitious social security reform. Part of the reason for this may have been that it realized that such a move would have conflicted with its efforts to obtain broad labor union support for a new incomes policy. These proved temporarily successful when severe economic circumstances convinced even the strongest traditional proponents of voluntarism-the craft unions-of the need to support centralized bargaining in late 1974. When general unions such as the TGWU subsequently came to use their superior numbers to push for egalitarian wage settlements, craft union leaders soon changed their mind, though. In as early as 1976, the General Council received the first letters from craft unions announcing that they were no longer willing to adhere to TUC policy because of the "wage anomalies" it produced. When other craft unions seeking to restore lost differentials followed suit in subsequent years, causing a series of competitive wage increases that reversed all 
of the gains made in the fight against inflation in previous years, Labour officials received a powerful reminder that the occupational defense of the wage differential was still quite successful. ${ }^{82}$

\section{Conclusion: Occupational Unionism and the Limits of the Modern Welfare State}

This article has sought to illustrate the crucial role played by the TUC and its occupationally organized affiliates in the failure of Labour's postwar social agenda. It has done so by showing that this agenda had major consequences for the distribution of income among different groups of workers and that these consequences were strongly resisted by occupationally organized unions representing privileged workers. The analysis first illustrated that these unions fiercely resisted Labour's attempts to introduce redistributive features into the egalitarian national insurance system - whether in the form of a more redistributive system of contributions and benefits or through measures that increased the scope for risk redistribution. It then illustrated that they also resisted other instances of redistributive government intervention such as the introduction of the statutory national minimum wage, and were thus quite unwilling to make wage sacrifices in order to improve wages and benefits for their lower-paid and more risk-prone coworkers. The analysis emphasized that the opposition of Britain's occupationally organized unions to redistributive measures was consistent, persistent, and often quite successful. To explain the latter, I emphasized that the skilled nature of their membership gave these unions substantial economic leverage over both the TUC and the Labour Party.

The analysis presented here suggests that measures that aim to make sure that all workers can obtain adequate earnings and insurance against labor market risk may be much more difficult to implement in countries where privileged workers largely organize separately from other workers. In such countries, the persistence of "precarious" forms of labor cannot only be attributed to pressure by business groups or the activities of liberal or conservative governments, but also to the resistance of occupationally organized unions to any measure that would work to reduce the occupational wage differential. It is crucial to note that the United Kingdom differed greatly in this respect from most of its continental European neighbors where a more inclusive type of unionism dominated. In the Netherlands, for instance, and as we have seen, the industrially organized union movement pushed for a redistributive public pension scheme that combined flat-rate benefits with earnings-related contributions at roughly the time when the TUC opposed a Labour proposal to do exactly the same in the United Kingdom. There is no evidence that this proposal was controversial in Dutch union circles. The union movements in other continental European countries also regularly supported redistributive social security proposals as well as wage outcomes that aimed to grant higher-than-average wage increases to the lowest paid. The absence of powerful occupationally organized unions there surely facilitated this.

The failure of Labour's efforts to improve the social insurance system and introduce an effective floor under wages made the emergence of a dual welfare 
system inevitable in the United Kingdom. This suggests that such systems are likely to emerge in countries where unions representing workers with a strong position on the labor market are able to obtain high wages and generous provision against labor market risk for their members through private bargaining, and at the same time resist measures that aim to improve matters for those workers who cannot obtain adequate earnings and benefits through private bargaining. As we have seen, Britain's occupationally organized unions did not oppose these measures because the emergence of generous private provision worked to "reorient" their interests. Nor, for that matter, did they oppose government intervention in the labor market because of an ideological commitment to voluntarism or because they were reluctant to hand over key union functions to a potentially hostile government. Instead, they did so because they realized very well that these measures had redistributive consequences that worked to the disadvantage of their members.

\section{NOTES}

1. In consecutive years, Labour's agenda would be much less ambitious and consist mostly of modest improvements to existing social security programs. Although the introduction of a statutory national minimum wage remained an official goal of the Labour Party, it would not actively advocate its introduction until the late 1980s.

2. See, for instance, Helen Fawcett, "The Beveridge Strait-Jacket: Policy Formation and the Problem of Poverty in Old Age," Contemporary British History 10 (1996): 37-38; Leslie Hannah, Inventing Retirement: the Development of Occupational Pensions in Britain (Cambridge, 1986), 56.

3. For some prominent examples, see Gøsta Esping-Andersen, The Three Worlds of Welfare Capitalism (Princeton, 1998), 151; Richard Hyman, Understanding European Trade Unionism: Between Market, Class and Society (London, 2001), 171; David Metcalf, Kristine Hansen, and Andy Charlwood, "Unions and the Sword of Justice: Unions and Pay Systems, Pay Inequality, Pay Discrimination and Low Pay," National Institute Economic Review 176 (2001): 61; Jacob Hacker, The Divided Welfare State: The Battle over Public and Private Social Benefits in the United States (Cambridge, 2002), 124; Jennifer Klein, For All These Rights: Business, Labor, and the Shaping of America's Public-Private Welfare State (Princeton, 2004), 4-5; Jonas Pontusson, Inequality and Prosperity: Social Europe versus Liberal America (Ithaca, 2006), 63; Torben Iversen and David Soskice, "Distribution and Redistribution: The Shadow of the Nineteenth Century," World Politics 61 (2009): 463.

4. Even early power resources theorists recognized the distinction between occupational and industrial unionism. To them, the importance of union structure lay foremost in the degree to which it extended labor's organizational power against capital though. See, for example, Walter Korpi, The Democratic Class Struggle (London, 1983), 39.

5. For an excellent criticism of the scholarly tendency to assume that "there is a practical equivalence of interests among like classes in different countries," see Peter Swenson's Capitalists Against Markets: The Making of Labor Markets and Welfare States in the United States and Sweden (Oxford, 2002), 8.

6. See, for example, Lewis Minkin, The Contentious Alliance: Trade Unions and the Labour Party (Edinburgh, 1991), 428; Howard Gospel and Gill Palmer, British Industrial Relations (London, 1994), 208; David Metcalf, "The British National Minimum Wage," British Journal of Industrial Relations 16 (1999): 172; Michael Terry, Redefining Public Sector Unionism: UNISON and the Future of Trade Unions (London, 2000), 157; Blackburn, Sheila, A Fair Day's Wage for a Fair Day's Work? Sweated Labour and the Origins of Minimum Wage Legislation in Britain (Aldersthot, 2007), 185-87.

7. Chris Pond and Steve Winyard, The Case for a National Minimum Wage (London, 1983), 37; Jill Rubery and Paul Edwards, "Low Pay and the National Minimum Wage," in 
Industrial Relations: Theory and Practice, ed. Paul Edwards (Oxford, 2003), 460; Department of Employment and Productivity, In Place of Strife: a Policy for Industrial Relations (London, 1969).

8. "Welfare systems" differ from "welfare states" here in that they also include privateespecially occupationally organized-benefits.

9. For recent criticisms of the longstanding preoccupation with class conflict in the literature, see, for instance, Swenson, Capitalists Against Markets, 8; Isabela Mares, The Politics of Social Risk: Business and Welfare State Development (Cambridge, 2003), 229. For some responses to these criticisms, see Walter Korpi, "Power Resources and Employer-Centered Approaches in Explanations of Welfare States and Varieties of Capitalism: Protagonists, Consenters, and Antagonists," World Politics 58 (2006): 167-206; David E. Broockman, "The 'Problem of Preferences': Medicare and Business Support for the Welfare State," Studies in American Political Development 26 (2012): 1-24.

10. According to Walter Korpi, for instance, "at the most general level we can distinguish three socio-economic classes: employers, employees, and the self-employed. Although internally quite heterogeneous, these broad categories define similarities in actors' opportunities and constraints, resources, and risks." Korpi, "Power Resources and Employer-Centered Approaches," 174. See also Esping-Andersen, The Three Worlds, 22-26.

11. See, for instance, David Bradley, Evelyne Huber, Stephanie Moller, Francois Nielsen, and John D. Stephens, "Distribution and Redistribution in Postindustrial Economies," World Politics 55 (2003): 193-228; Torben Iversen, Capitalism, Democracy, and Welfare (Cambridge, 2005), 154; Isabela Mares, Taxation, Wage Bargaining and Unemployment (Cambridge, 2006); Iversen and Soskice, Distribution and Redistribution, 448; Hyeok Yong Kwon and Jonas Pontusson, "Globalization, Labour Power and Partisan Politics Revisited," Socio-Economic Review 8 (2010): 251-81.

12. The main exponents of this variant are Swenson, Capitalists against Markets; Colin Gordon, Dead on Arrival: The Politics of Health Care in Twentieth-Century America (Princeton, 2003); Mares, The Politics of Social Risk.

13. See, for instance, Silja Häusermann, The Politics of Welfare Reform in Continental Europe: Modernization in Hard Times (Cambridge, 2010), 70-75.

14. For the assumption of union support of British welfare state development, see, for instance, Helen Fawcett, "Jack Jones, the Social Contract and Social Policy 1970-1974," in Welfare Policy in Britain. The Road from 1945, ed. Helen Fawcett and Rodney Lowe (London, 1999), 158; Michael Hill, The Welfare State in Britain. A Political History Since 1945 (Brookfield, 1993), 108; Rodney Lowe, The Welfare State in Britain since 1945 (London, 1998), 2; Mares, Taxation, Wage Bargaining and Unemployment, 177 and 205-6; and Noel Whiteside, "Industrial Relations and Social Welfare, 1945-1979," in A History of British Industrial Relations, 1939-1979. Industrial Relations in a Declining Economy, ed. C. J. Wrigley (Cheltenham, 1996), 121.

15. Recent writings have gone to great lengths to explain how employers managed to tilt welfare systems toward greater reliance on private provision because labor unions lacked the political clout to push for an extension of universal public benefits for all workers. This view of the emergence of "dualized welfare systems" is not different from those of traditional classoriented writings, which argued that they were deliberately created to "divide wage-earners." Gøsta Esping-Andersen and Walter Korpi, "Social Policy as Class Politics in Post-War Capitalism: Scandinavia, Austria, and Germany," in Order and Conflict in Contemporary Capitalism, ed. John H. Goldthorpe (Oxford, 1984), 184. See also Walter Korpi and Joakim Palme, "The Paradox of Redistribution and Strategies of Equality: Welfare State Institutions, Inequality and Poverty in Western Countries," American Sociological Review 63 (1998), 661-87.

16. See, for instance, Wolfgang Streeck, "The Sociology of Labor Markets and Trade Unions," in The Handbook of Economic Sociology, ed. N. J. Smelser and R. Swedberg (Princeton, 2005), 269; Matthieu Leimgruber, Solidarity without the State? Business and the Shaping of the Swiss Welfare State, 1890-2000 (Cambridge, 2008), 19, 169-72; Gordon, Dead on Arrival, 275.

17. Marie Gottschalk, The Shadow Welfare State. Labor, Business, and the Politics of Health Care in Twentieth-Century America (Ithaca, 2000), 2. See also Gordon, Dead on Arrival, 281; Hacker, The Divided Welfare State, 130-34; Leimgruber, Solidarity Without the State, 209-12.

18. Swenson, Capitalists against Markets, 8 . In his otherwise seminal work, Peter Swenson largely assumes that organized labor in Sweden and the United States, despite their strong 
internal differences, were largely motivated by the same goals and considerations. Yet given the well-documented concerns of American craft unions "to remain above the unskilled proletariat," it is highly unlikely that they were motivated by the same considerations as Sweden's industrially organized unions. Gary Marks, Unions in Politics: Britain, Germany, and the United States in the Nineteenth and Early Twentieth Centuries (Princeton, 1989), 46.

19. Mares, Taxation, Wage Bargaining and Unemployment, 218.

20. Silja Häusermann, "Solidarity with Whom? Why Trade Unions are Losing Ground in Continental Pension Politics," European Journal of Political Research 49 (2010): 223-256.

21. Many scholars nevertheless proceed to apply simply median-voter models to explain union behavior. See, for instance, Pontusson, Inequality and Prosperity, 60-61; Alison L. Booth, The Economics of the Trade Union (Cambridge, 1995), 108-16; Iversen and Soskice, "Distribution and Redistribution," 448; Mares, The Politics of Social Risk, 47.

22. On this see, for instance, George Sayers Bain, The Growth of White-Collar Unionism (Oxford, 1970).

23. The United Kingdom had few true industrial unions, and even these organized fewer grades of workers. The result was that most unions either organized in occupationally organized unions or in so-called general unions that mostly catered for lower and unskilled workers. For a more elaborate account of this, see Bernhard Ebbinghaus and Jeremy Waddington, "United Kingdom/Great Britain," in The Societies of Europe. Trade Unions in Western Europe since 1945, ed. Bernhard Ebbinghaus and Jelle Visser (Basingstoke, 2000), 706-56.

24. The share of craft unions in the total union membership had been decreasing from the late nineteenth century on as semi- and unskilled manual workers increasingly began to organize. What once had been the organizational "backbone" of the union movement represented only a fraction of all organized workers (some ten to fifteen percent) by the end of the twentieth century. Nevertheless, the manual wage distribution remained the same from 1880 to 1980 . See Chris Pond, "Low Pay-1980s Style," Low Pay Review 4 (1981): 1-10.

25. An excellent example of this is the Netherlands, where the industrially organized union movement often pushed for bargaining outcomes and social security initiatives that benefited a minority of workings in the lowest decile of the wage distribution, and which were paid for by the vast majority of other (unionized) workers. See, for instance, Dennie Oude Nijhuis, "Revisting the Role of Labor: Worker Solidarity, Employer Opposition, and the Development of Old-Age Pensions in the Netherlands and the United Kingdom," World Politics 61 (2009): 296-329.

26. For some prominent examples, see Minkin, The Contentious Alliance, 429; Geoffrey Finlayson, Citizen, State, and Social Welfare in Britain, 1830-1990 (Oxford, 1994), 123; Alan Campbell, Nina Fishman, and John McIlroy, "The Post-War Compromise: Mapping Industrial Politics, 1945-1964," in British Trade Unions and Industrial Politics. Volume One: the Post-war Compromise, 1945-1964, ed. Alan Campbell, Nina Fishman, and John McIlroy (Aldershot, 1999), 76; Howell, Trade Unions, 170.

27. Over the years, many scholars have noted that craft unions representing skilled manual workers were generally far more resistant to government interference with the wage bargaining process than were general unions representing unskilled and semiskilled manual workers. See, for instance, Hugh Clegg, The Changing System of Industrial Relations in Britain (Oxford, 1979), 436-37; Henry Pelling, A History of British Trade Unionism (London: Macmillan, 1971), 236.

28. According to Alan Flanders, for instance, "[N]aturally at times or in areas of industrial weakness there has been the greatest readiness to resort to the method of legal enactment, either because collective bargaining was unavailable or else because its results were unacceptable." Allan Flanders, "The Tradition of Voluntarism," British Journal of Industrial Relations 12 (1974): 358.

29. See, for instance, Blackburn, A Fair Day's Wage, 185-86.

30. In the words of the TUC, it was to be "confined to the trades where there was practically no Trade Union organisation." MRC, MSS.292/110/2: Notes on wage fixing machinery, January 15, 1945, 1 .

31. Derek Fraser, The Evolution of the British Welfare State: a History of Social Policy since the Industrial Revolution (London, 2003), 252.

32. Hugh Pemberton, "Politics and Pensions in Post-War Britain," in Britain's Pensions Crisis: History and Policy, ed. Hugh Pemberton, Pat Thane, and Noel Whiteside (Oxford, 2006), 43. 
33. José Harris, William Beveridge: a Biography (Oxford, 1997), 409.

34. MRC, MSS.292/150.5/3: Relation TUC General Council Scheme and Plan for Social Security in Sir William Beveridge's Report, 1943.

35. On this rejection, see MRC, MSS.200/160/3: Social Insurance and Industrial Welfare Committee, Minutes, March 10, 1954 and April 14, 1954.

36. Oude Nijhuis, "Revisting the Role of Labor," 310-11.

37. On union attitudes toward public pension reform in this period, see, for instance, Peter Baldwin, The Politics of Social Solidarity. Class Bases of the European Welfare State 1875-1975 (Cambridge, 1990), 202-3.

38. See, for instance, Nils Elvander, "Die Gewerkschaftsbewegung in Schweden: Geschichte, Programm, politische Beziehungen," in Gewerkschaften in den Demokratien Westeuropas, ed. Hans Ruehle and Hans-Joachim Veen (Munich, 1983), 344-45.

39. That the Labour government realized this at the time became quite clear when government representative Ernest Bevin, in an attempt to obtain TUC support for wage restraint, suggested that "the Government might be assisting the General Council by making no reference to the low-paid since this would raise the question of differentials." MRC, MSS.292/110.44/2b: Special Committee on the economic situation, November 14, 1949, 6.

40. See Baldwin, The Politics of Social Solidarity, 233.

41. For the citation and demands for an opt-out, see MRC, MSS.292/166.21/2a: National Superannuation. Proposed meeting with Labour Party. May 14, 1958. MRC, MSS.292/161/14: Appendix Minutes Social Insurance and Industrial Welfare Committee, March 13, 1957.

42. MRC, MSS.292/166.21/2b: Report meeting TUC and Home Policy Committee Labour Party, February 27, 1957.

43. For these and other objections to Labour's plans, see Baldwin, The Politics, 238.

44. See, for instance, Fawcett, "The Beveridge Strait-Jacket," 25-26.

45. While Labour had proposed giving a sixty percent replacement rate on earnings up to half the national average, resulting in a rather abrupt reduction in the marginal rate of the benefit at a relatively low level of earnings, the TUC now suggested a forty percent replacement rate up to national earnings, and, like Labour, twenty-five percent over higher earnings. MRC, MSS.292B/166.5/.2: Economic Aspects of the Government's National Superannuation and Social Insurance Proposals-note on Memorandum by the Secretary of State for Social Services, April 2, 1969.

46. On this, see Baldwin, The Politics of Social Solidarity, 244-45; Richard Crossman, The Backbench Diaries of Richard Crossman (London, 1981), 625-27.

47. See, for instance, Fawcett, "The Beveridge Strait-Jacket," 37-38; Hannah, Inventing Retirement, 56; Hugh Pemberton, "The Failure of 'Nationalization by Attraction': Britain's Cross-class Alliance Against Earnings-Related Pensions in the 1950s," Economic History Review 65 (2010): 1429-30.

48. MRC, MSS.292B/445.7/1: Occupational Pensions, March 9, 1970.

49. MRC, MSS.292B/166.5/1: TUC General Council Minutes, August 20, 1969.

50. MRC, MSS.166.5/1: Press Statement National Federation of Professional Workers, July 26, 1969.

51. The State Earnings Related Pension Scheme (SERPS), which was introduced by Labour in the mid-1970s, in effect did nothing more than offer a compulsory secondary pension program, which was more or less guaranteed by the state. The scheme did nothing for Britain's poorest pensioners.

52. MRC, MSS.292B/161.1: TUC Social Insurance and Industrial Welfare Committee, Minutes of Seventh Meeting, April 12, 1961.

53. Stanley Parker, Effects of the Redundancy Payments Act (London, 1971); Hilda Kahn, Repercussions of Redundancy (London, 1964), 21-24.

54. MRC, MSS 200/C/3/EMP/3/113: BEC Letter to Secretaries of Member Organisations on Security of Employment, February 23, 1959.

55. MRC, MSS.292B/161.1: TUC Social Insurance and Industrial Welfare Committee, Minutes of First meeting, January 11, 1962; MRC, MSS.292B/161.2: TUC Subcommittee on Sickness and Unemployment Benefits, Minutes of the Second Meeting, February 14, 1962.

56. MRC, MSS.292B/161.2: TUC Subcommittee on Sickness and Unemployment Benefits, Minutes of the Fourth Meeting, May 9, 1962.

57. This effectively ensured support from the TUC and BEC. See MRC, MSS.200/C/3/ EMP/5/1/: New national insurance legislation, August 23, 1965. 
58. One reason that it was able to do so was that its Conservative predecessor had paved the way by preparing a similar act in an attempt to improve labor mobility and workplace flexibility. On this, see Paul Bridgen, "The State, Redundancy Pay, and Economic Policy-Making in the Early 1960s," Twentieth Century British History 11 (2000): 233-58.

59. The statutory national minimum wage finally came into effect in April of 1999, at the brink of the new century, and over three decades after a Labour government had first proposed its introduction. Up to then, and among the member states of the European Union, only the United Kingdom and Ireland (which introduced a statutory national minimum wage in April of 2000) lacked a common floor for wages, as they had neither a statutory national minimum wage nor a functional equivalent in the form of minimum pay rates made possible by an extensive spread of collective bargaining.

60. See, for instance, Sheila Blackburn, "The Problem of Riches: From Trade Boards to a National Minimum Wage," Industrial Relations Journal 19 (1988): 131; Stephen Keevash, "Wages Councils: An Examination of Trade Union and Conservative Misconceptions about the Effect of Statutory Wage Fixing," Industrial Law Journal 14 (1985): 217-32.

61. Some scholars have argued however that "the predominance of unions representing relatively highly paid skilled workers within the union movement made the TUC unsympathetic to the need to provide a legislative floor to the wages and conditions of low-paid, unskilled workers." See Chris Howell, Trade Unions and the State: The Construction of Industrial Relations in Britain, 1890-2000 (Princeton, 2005), 460. Lewis Minkin also noted that "there was a worry that the policy might prove an inflationary lever as unions attempted to preserve differentials." But he clearly gives more importance to traditional voluntarist arguments by arguing that "[f]or years the tradition of free collective bargaining and anxiety over a possible undermining of union functions had been major obstacles to the Movement's support for a statutory minimum wage." Minkin, The Contentious, 428.

62. An internal TUC report on the matter would later confirm this. MRC, MSS.292B/ 115.4/3: Low pay: Report, February 11, 1970.

63. Largely confined to declining sectors or sectors with very low levels of union organization, only about half of all low paid were active in sectors covered by wage councils. This share would steadily decline in coming years. In addition, the minimum rates set by the wage councils were often far too low to solve the problem of low pay (sometimes they were as low as thirty percent of average earnings in the industry) and were frequently undercut by employers. See Pond and Winyard, The Case, 20-29; Juan Dolado et al., "The Economic Impact of Minimum Wages in Europe," Economic Policy 23 (1996): 353.

64. PRO, Lab10/2149: Working Party on a National Minimum Wage. Draft Report, December 31, 1964.

65. PRO, Lab 10/2228: Draft Report Working Party on a National Minimum Wage, February 22, 1965.

66. In addition, it aimed to improve matters for lower-paid workers by increasing family allowances, improving housing, and introducing school meals. PRO, BN 72/48: Minimum National Wage, note by R.S. Swift, September 26, 1967.

67. PRO, BN 72/48: Social Services Committee Meeting, November 5, 1968.

68. MRC, MSS.292B/115.4/3: Low pay: further appraisal. Annex, June 10, 1970.

69. Although the TGWU continues to express its doubts about the merits of statutory intervention, it did not oppose the introduction of a statutory national minimum wage when the General Council first supported this in the early 1980s. Nearly all occupational-organized unions continued to do so. On this, see for instance, Terry, Redefining Public Sector Unionism, 158; Minkin, The Contentious Alliance, 429. See also MRC, MSS.292D/116/6: Public Services Committee, Low Pay in the Public Services, July 5, 1983.

70. MRC, MSS.292B/115.4/3: Low pay: further appraisal in the light of union comments, June 10, 1970.

71. MRC, MSS.292B/115.4/3: Low pay: further appraisal in the light of union comments. Annex: Summary of union comments, June 10, 1970.

72. Ibid.

73. They would repeat this strategy on various occasions when confronted with new initiatives to introduce a statutory national minimum wage. On this, see, for instance, Dorey, Wage Politics in Britain, 222.

74. MRC, MSS.292B/115.4/4: LPWP, restructuring incomes and jobs, November 12, 1969.

75. MRC, MSS.292B/116/1: LPWP 4/3, December 2, 1969. 
76. MRC, MSS.292B/115.4/4: Statutory National Minimum Wage-some underlying considerations, December 2, 1969.

77. MRC, MSS.292B/115.4/3: Low pay: report, February 11, 1970.

78. MRC, MSS.292B/115.4/3: Low pay: further appraisal, June 10, 1970; MRC, MSS.292D/ 161/1: Minutes, November 11, 1970.

79. MRC, MSS.292B/115.4/3: Low pay: report of a working party, February 11, 1970.

80. MRC, MSS.292B/115.4/3: Low pay: further appraisal in the light of union comments, June 10, 1970.

81. Part of the reason for this was that the General Council still strongly resisted statutory intervention, which "did not yet have the support of the whole trade union movement." MRC, MSS.292D/160.31/2: Social Policy Subcommittee, October 7, 1976.

82. For an excellent overview of events, see Robert Taylor, "The Trade Union 'Problem' in British Politics," in Trade Unions in British Politics, ed. Ben Pimlot and Christopher Cook (London, 1982), 202-7. 